\title{
Fluorescent pseudomonads associated with the phyllosphere of grasses; Pseudomonas trivialis sp. nov., Pseudomonas poae sp. nov. and Pseudomonas congelans sp. nov.
} Correspondence
Undine Behrendt
ubehrendt@zalf.de

\author{
Undine Behrendt, ${ }^{1}$ Andreas Ulrich ${ }^{2}$ and Peter Schumann ${ }^{3}$
}

Strains of fluorescent pseudomonads, isolated from the phyllosphere of grasses, were analysed by a polyphasic approach in order to clarify their interspecific position. Classification on the basis of ribotyping revealed six genotypes; four of these, which could be differentiated clearly from each other and from Pseudomonas species with validly published names on the basis of phenotypic features, were chosen for detailed phylogenetic analysis. DNA-DNA hybridization studies among representative strains of the four genotypes and closely related Pseudomonas species, determined by comparison of $16 \mathrm{~S}$ rDNA sequences, showed that three of the studied ribotypes represented novel species. Two of them were related to mainly saprophytic fluorescent pseudomonads and could be easily distinguished by a negative arginine dihydrolase reaction. One ribotype, also characterized by a negative arginine dihydrolase reaction, was closely related to potentially plant-pathogenic fluorescent pseudomonads and differed in certain phenotypic features from its phylogenetic neighbours. As a consequence of the phenotypic and phylogenetic analyses, Pseudomonas trivialis sp. nov. (type strain: $\mathrm{P} 513 / 19^{\top}=\mathrm{DSM} 14937^{\top}=\mathrm{LMG} 21464^{\top}$ ), Pseudomonas poae sp. nov. (type strain: $\mathrm{P} 527 / 13^{\top}=\mathrm{DSM} 14936^{\top}=\mathrm{LMG} 21465^{\top}$ ) and

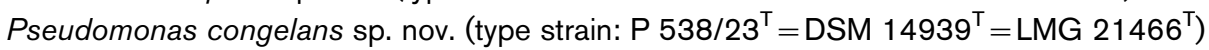
are proposed.

Fluorescent pseudomonads are typical inhabitants of the phyllosphere and are involved in several interactions with plants (Schroth et al., 1992). Some species have a strictly commensal relationship with their host plants. Furthermore, potentially phytopathogenic pseudomonads can be found on their specific hosts, as well as on plant species that are not susceptible to these pathogens.

\footnotetext{
Published online ahead of print on 28 February 2003 as DOI 10.1099/ ijs.0.02567-0.

The GenBank/EMBL/DDBJ accession numbers for the 16S rDNA sequences analysed in this study are AJ492831 (Pseudomonas trivialis P 513/19 ${ }^{\top}=$ DSM $14937^{\top}=$ LMG $21464^{\top}$ ), AJ492829 (Pseudomonas poae $\left.\mathrm{P} \quad 527 / 13^{\top}=\mathrm{DSM} \quad 14936^{\top}=\mathrm{LMG} \quad 21465^{\top}\right), \quad$ AJ492828 $\left(P\right.$ seudomonas congelans P $538 / 23^{\top}=$ DSM $14939^{\top}=$ LMG $21466^{\top}$ ), AJ492830 (genotype E1 P 515/12=DSM 14938=LMG 21467), AJ492826 (Pseudomonas tremae CFBP $6111^{\top}$ ) and AJ492827 (Pseudomonas cannabina CFBP 2341 ${ }^{\top}$ ).
}

Studies of bacterial communities that live in the phyllosphere of grasses showed that predominantly fluorescent Pseudomonas species comprised most Gram-negative bacteria present (Behrendt, 2001). Most of them were phenotypically highly similar to the saprophytic species Pseudomonas fluorescens or to Pseudomonas syringae, a potentially phytopathogenic bacterium. Moreover, strains that showed physiological similarity to the phytopathogenic species Pseudomonas viridiflava or Pseudomonas cichorii were isolated, but their taxonomic affiliations were ambiguous. Thus, a selection of these strains was characterized by a polyphasic approach to clarify their interspecific position within the genus Pseudomonas.

\section{Isolation of strains from the phyllosphere}

Samples of grass plots, characterized by different intensities of management, were taken to investigate the community structures of heterotrophic bacteria, as described by Behrendt (2001). Grass material was homogenized in 
distilled water by using a Stomacher lab blender and serial dilutions were plated on nutrient agar (SIFIN), supplemented by $0.4 \mathrm{~g}$ cycloheximide $1^{-1}$, to obtain selectivity for bacterial growth. After incubation at $21^{\circ} \mathrm{C}$ for 7 days, a representative number of strains was isolated to determine the community structure of culturable heterotrophic bacteria. Isolates were subjected to taxonomic investigations; one set of strains of fluorescent pseudomonads showed a negative arginine dihydrolase reaction and an indefinite taxonomic affiliation after physiological characterization by both conventional tests and application of the commercial Biolog identification system. These strains were used for further studies. Strain numbers of isolates studied and type strains used for comparison are shown in Table 1.

\section{Phylogenetic analysis}

To classify the isolates on the basis of phylogenetic heterogeneity, restriction analysis of $16 \mathrm{~S}$ rDNA was performed according to Behrendt et al. (1999). 16S rRNA genes were amplified with primers described by Weisburg et al. (1991), resulting in amplification of a single fragment of approximately $1500 \mathrm{bp}$. Digestion of these PCR products by a set of endonucleases (TaqI, HinfI, AluI, MspI, CfoI, HaeIII and $\mathrm{ScrFI}$ ) showed identical patterns for almost all isolates; only two, P 516/20 and P 538/23, revealed differences in patterns for two of the enzymes (AluI and $S c r F I)$. These results indicate high $16 \mathrm{~S}$ rDNA sequence similarity. Thus, genetic classification of strains according to differences in physiological features could not be carried out by using this method. In order to classify the isolates by a method of higher taxonomic resolution, strains were studied by ribotyping with the restriction enzyme EcoRI, which was species-specific within the genus Pseudomonas (Sikorski et al., 2001). These analyses were performed with the automated RiboPrinter Microbial Characterization system (Qualicon DuPont). Band patterns were compared by using the BioNumerics software (Applied Maths). Clustering was carried out by UPGMA based on Pearson's correlation coefficient (optimization coefficient, $1 \cdot 2 \%$ ). This procedure revealed grouping of isolates into six genotypes (Fig. 1). Four of these genotypes (A, B, D and E1), which had similarities between ribopatterns of $<60 \%$, were chosen for further phylogenetic studies. Strains of genotype $\mathrm{C}$ were not considered, as no effective physiological characteristics were found to differentiate them clearly from isolates of genotype A (Table 2). Although a few

Table 1. Reference and isolated grass-associated strains used in this study

Abbreviations: ATCC, American Type Culture Collection, Manassas, VA, USA; CCEB, Institute of Entomology, CSAV Czechoslovak Academy of Sciences, Department of Insect Pathology, Prague, Czech Republic; CFBP, Collection Française des Bactéries Phytopathogènes, Angers, France; CFML, Collection de la Faculté de Médecine de Lille, Lille, France; CIP, Collection de l'Institut Pasteur, Paris, France; DSM, Deutsche Sammlung von Mikroorganismen und Zellkulturen, Braunschweig, Germany; IAM, Institute of Applied Microbiology, University of Tokyo, Institute of Molecular and Cellular Bioscience, Tokyo, Japan; ICMP, International Collection of Microorganisms from Plants, Plant Disease Division, DSIR, Auckland, New Zealand; LMG, Laboratorium voor Mikrobiologie, Universiteit Gent, Gent, Belgium; NCIB $(=\mathrm{NCIMB}=\mathrm{NCMB})$, National Collection of Industrial and Marine Bacteria, Aberdeen, UK; NCPPB, National Collection of PlantPathogenic Bacteria, Central Science Laboratory, York, UK; P, culture at the collection in the Institute of Primary Production and Microbial Ecology, Centre for Agricultural Landscape and Land Use Research Müncheberg (ZALF), Paulinenaue, Germany; PDDCC, Plant Division Culture Collection, New Zealand Department of Scientific and Industrial Research, Auckland, New Zealand.

\begin{tabular}{|c|c|}
\hline Species/ribotype & Strains \\
\hline Pseudomonas cannabina & CFBP $2341^{\mathrm{T}}\left(=\mathrm{ICMP} 2823^{\mathrm{T}}=\mathrm{NCPPB} 1437^{\mathrm{T}}\right)$ \\
\hline Pseudomonas cedrina & CIP $105541^{\mathrm{T}}\left(=\right.$ CFML $\left.96-198^{\mathrm{T}}\right)$ \\
\hline Pseudomonas rhodesiae & DSM $14020^{\mathrm{T}}\left(=\right.$ CFML $92-111^{\mathrm{T}}=$ CIP $\left.104664^{\mathrm{T}}=\mathrm{NCIMB} 13509^{\mathrm{T}}\right)$ \\
\hline Pseudomonas savastanoi pv. glycinea & LMG $5066(=$ ICMP $2189=$ NCPPB $2411=$ PDDCC 2189$)$ \\
\hline Pseudomonas synxantha & LMG $2190^{\mathrm{T}}\left(=\right.$ ATCC $9890^{\mathrm{T}}=$ CCEB $\left.607^{\mathrm{T}}=\operatorname{CIP} 59.22^{\mathrm{T}}=\operatorname{IAM} 12356^{\mathrm{T}}=\mathrm{NCIB} 8178^{\mathrm{T}}\right)$ \\
\hline Pseudomonas tremae & CFBP $6111^{\mathrm{T}}\left(=\operatorname{ICMP} 9151^{\mathrm{T}}=\mathrm{NCPPB} 3465^{\mathrm{T}}\right)$ \\
\hline Pseudomonas veronii & DSM $11331^{\mathrm{T}}\left(=\operatorname{CIP} 104663^{\mathrm{T}}\right)$ \\
\hline \multicolumn{2}{|l|}{ Ribotype: } \\
\hline A (Pseudomonas trivialis) & $\begin{array}{l}\text { P } 513 / 19^{\mathrm{T}}\left(=\mathrm{DSM} 14937^{\mathrm{T}}=\mathrm{LMG} 21464^{\mathrm{T}}\right), \text { P 514/01, P 517/12, P 517/22, P 527/30, } \\
\text { P 528/25, P 530/13 }\end{array}$ \\
\hline B (Pseudomonas poae) & P $527 / 13^{\mathrm{T}}\left(=\mathrm{DSM} 14936^{\mathrm{T}}=\mathrm{LMG} 21465^{\mathrm{T}}\right)$, P $527 / 10$, P $529 / 17$ \\
\hline $\mathrm{C}$ & P 501/02, Р 501/16, P 515/18, P 527/17, P 527/22 \\
\hline $\mathrm{D}$ (Pseudomonas congelans) & P $538 / 23^{\mathrm{T}}\left(=\mathrm{DSM} 14939^{\mathrm{T}}=\mathrm{LMG} 21466^{\mathrm{T}}\right), \mathrm{P} 516 / 20$ \\
\hline E1 & P 515/12 (=DSM 14938=LMG 21467), P 515/10, P 530/23, P 517/04 \\
\hline E2 & P $515 / 15$, P $515 / 17$ \\
\hline
\end{tabular}




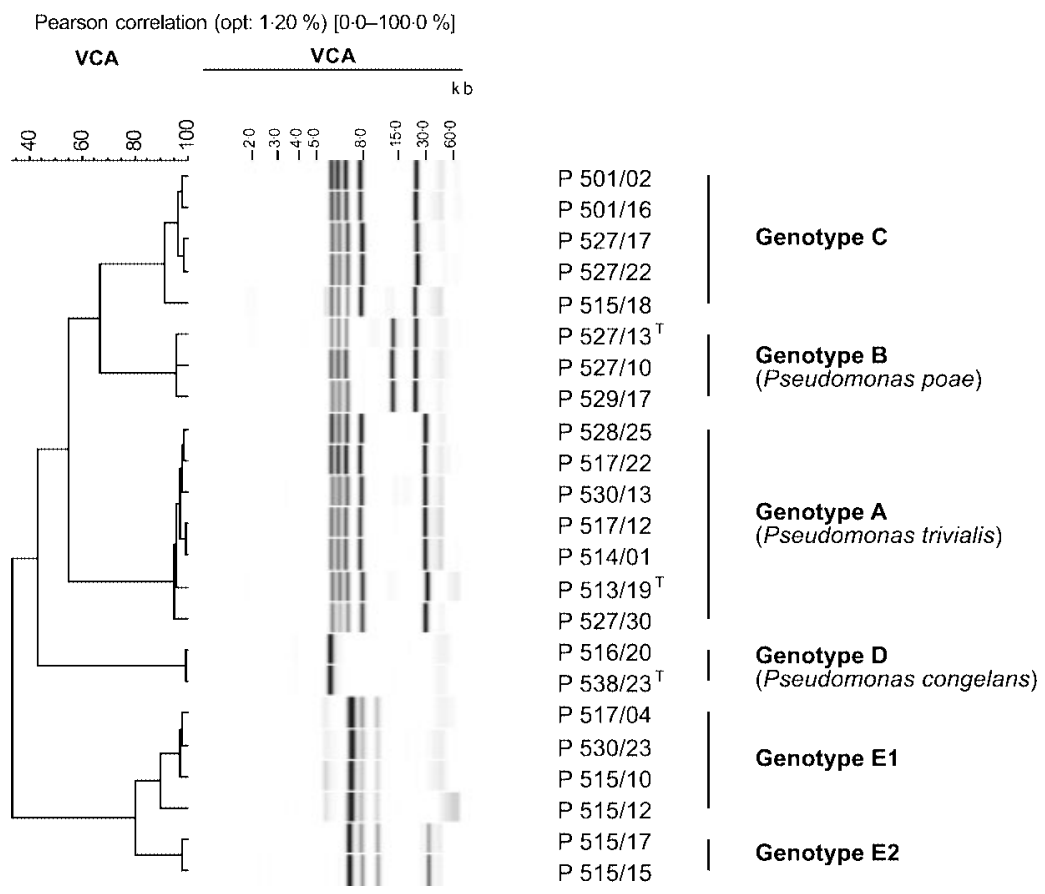

Fig. 1. Riboprint patterns of EcoRIrestricted DNA of the grass isolates studied. Analysis was done with the RiboPrinter Microbial Characterization system (Qualicon DuPont). The riboprint pattern was analysed with the BioNumerics software package GeneExplore version 1.0 (Applied Maths). VCA, RiboPrinter internal designation for an EcoRI batch.

phenotypic features were found that differentiated ribotype E2 from E1, the former was also excluded from further studies due to high similarity between ribopatterns.

Sequencing of amplified 16S rDNA of strains representative for the selected genotypes was performed by using a BigDye Terminator Cycle Sequencing kit (Applied Biosystems) and the primer described by Chun \& Goodfellow (1995). For phylogenetic analysis, 16S rDNA sequences of 77 strains,

Table 2. Physiological characteristics that differ between the genotypes of grass isolates, as determined by ribotyping

+, Positive; -, negative; D, different reaction between tested strains (reaction of type strain in parentheses); W, weak.

\begin{tabular}{|lccccccc}
\hline \multirow{2}{*}{ Characteristic } & \multicolumn{7}{c|}{ Ribotype } \\
\cline { 2 - 7 } & $\mathbf{A}^{*}$ & B $\dagger$ & $\mathbf{C}$ & $\mathbf{D} \neq$ & $\mathbf{E 1}$ & E2 \\
\hline No. tested strains $(n)$ & 7 & 3 & 5 & 2 & 4 & 2 \\
Oxidase & $\mathrm{W}$ & $\mathrm{W}$ & $\mathrm{W}$ & - & + & + \\
Casein hydrolysis & $\mathrm{D}(-)$ & $\mathrm{D}$ & $(-)$ & + & + & - & - \\
Ice nucleation activity & - & - & $\mathrm{D}$ & + & - & - \\
Utilization of: & & & & & & & \\
$\quad$ D-Sorbitol & $\mathrm{D}(-)$ & - & + & + & - & - \\
$\quad$ Sucrose & - & + & $\mathrm{D}$ & + & - & - \\
$\quad \mathrm{D}-$ Trehalose & + & + & + & + & - & + \\
$\alpha$-Ketovaleric acid & + & - & + & - & + & $\mathrm{D}$ \\
$i$-Erythritol & - & - & - & + & - & - \\
$p$-Hydroxyphenylacetic acid & $\mathrm{D}(-)$ & - & - & - & - & + \\
& & & & & & & \\
\hline
\end{tabular}

*Pseudomonas trivialis.

$\dagger$ Pseudomonas poae.

$\ddagger$ Pseudomonas congelans. that represented type strains of all authentic species of the genus Pseudomonas were chosen (except for Pseudomonas gelidicola, for which no $16 \mathrm{~S}$ rDNA sequence was available). Furthermore, some strains that represented species without validly published names were involved. Sequences were aligned by using the CLUSTALX algorithm (Thompson et al., 1997) and trees were constructed by using the neighbourjoining (Saitou \& Nei, 1987) and maximum-likelihood (Felsenstein, 1981) algorithms (PHYLIP version 3.57; Felsenstein, 1993). Both trees showed that the investigated isolates clustered clearly within the genus Pseudomonas (data not shown). Species that formed a closely related cluster with the grass isolates were selected for more detailed phylogenetic analyses. A phylogenetic tree based on 1282 nt (Escherichia coli positions 99-1376) was constructed for this subset of species, as shown in Fig. 2.

Representative strains of genotypes A, B and E1 clustered at a branch that corresponds to the ' $P$. fluorescens group' of Anzai et al. (2000), whereas the strain with genotype $\mathrm{D}$ was in the ' $P$. syringae group'. As indicated by restriction analysis of $16 \mathrm{~S}$ rDNA, sequences were highly similar among grass isolates. In particular, a comparison of genotypes A and B revealed $99.93 \%$ similarity. The closest phylogenetic neighbours of both isolates were Pseudomonas veronii and Pseudomonas rhodesiae, with a similarity between 99.3 and $99.4 \%$ (based on a binary comparison of the available length of sequences). The representative strain of genotype E1 displayed highest similarity to Pseudomonas cedrina (99.9\%) and Pseudomonas synxantha $(99.0 \%)$, whereas the closest phylogenetic neighbours of genotype D were pathovars of Pseudomonas savastanoi, which displayed similarities of $99 \cdot 6-99 \cdot 8 \%$. Such high conformity in $16 \mathrm{~S}$ rDNA sequence between species was, to a 


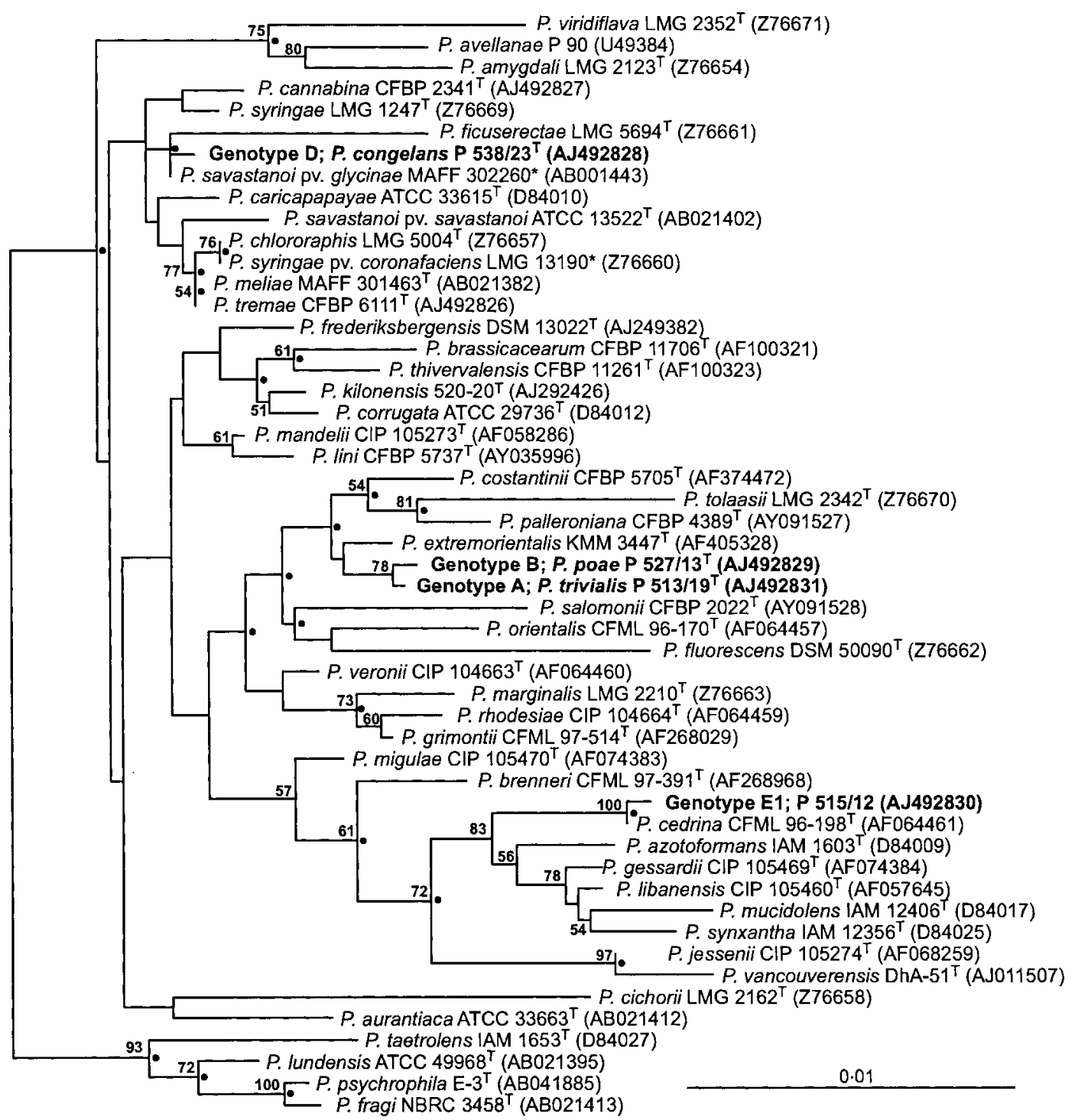

Fig. 2. Phylogenetic tree showing the relationships of the strains studied within a subset of closely related Pseudomonas species. The tree is based on a 1282 bp alignment of $16 \mathrm{~S}$ rDNA sequences and was constructed by using the neighbourjoining method (Saitou \& Nei, 1987). Dots indicate branches of the tree that were also formed by using the maximumlikelihood method (Felsenstein, 1981). To estimate the root position of the tree, E. coli (GenBank accession no. J01695) was used as an outgroup. Values are the number of times that a branch appeared in 100 bootstrap replications. Strains characterized in this study are in bold. *Pathovar reference strain. Bar, 0.01 relative sequence divergence.

large extent, found in the studied subset of pseudomonads shown in Fig. 2. Accordingly, most bootstrap values were relatively low and only certain branches were confirmed by the topology of the maximum-likelihood tree.

To clarify the interspecific position of the investigated genotypes, DNA-DNA hybridization studies were performed according to a method described previously (Martin et al., 1997). Representative strains of genotypes were tested against each other and against species with validly published names that were the closest phylogenetic neighbours, as estimated by binary comparison of $16 \mathrm{~S}$ rDNA sequences. As shown in Table 3, all tested pairings of genotypes $\mathrm{A}, \mathrm{B}$ and $\mathrm{D}$ resulted in reassociation values $<70 \%$, indicating separate species status. However, hybridization studies between genotype $\mathrm{E} 1$ and $P$. cedrina revealed similarities of 76.4 and $78.3 \%$, suggesting an affiliation to the species $P$. cedrina.

\section{Morphological and physiological characterization}

Morphological and physiological characterization was performed as described by Behrendt et al. (1999). All grass isolates studied were Gram-negative, non-sporeforming, rod-shaped organisms that occurred as single 
Table 3. DNA reassociation values (\%) among Pseudomonas strains tested

\begin{tabular}{|c|c|c|c|c|}
\hline \multirow[t]{2}{*}{ Strain } & \multicolumn{4}{|c|}{ Genotype } \\
\hline & A & B & D & E1 \\
\hline Pseudomonas trivialis $\mathrm{P} 513 / 19^{\mathrm{T}}$ (genotype A) & - & $60 \cdot 0$ & $32 \cdot 9$ & $53 \cdot 7$ \\
\hline Pseudomonas poae $\mathrm{P} 527 / 13^{\mathrm{T}}$ (genotype B) & $60 \cdot 0$ & - & $29 \cdot 5$ & $50 \cdot 7$ \\
\hline Pseudomonas congelans $\mathrm{P} 538 / 23^{\mathrm{T}}$ (genotype D) & $32 \cdot 9$ & $29 \cdot 5$ & - & $29 \cdot 0$ \\
\hline Genotype E1 (P 515/12) & $53 \cdot 7$ & $50 \cdot 7$ & $29 \cdot 0$ & - \\
\hline Pseudomonas rhodesiae DSM $14020^{\mathrm{T}}$ & $43 \cdot 8$ & $41 \cdot 7$ & - & - \\
\hline Pseudomonas veronii DSM $11331^{\mathrm{T}}$ & $41 \cdot 5$ & $31 \cdot 7$ & - & - \\
\hline Pseudomonas savastanoi pv. glycinea LMG $5066^{*}$ & - & - & $44 \cdot 8$ & - \\
\hline Pseudomonas synxantha LMG $2190^{\mathrm{T}}$ & - & - & - & $48 \cdot 9$ \\
\hline Pseudomonas cedrina CIP $105541^{\mathrm{T}}$ & - & - & - & $76 \cdot 4 \dagger$ \\
\hline
\end{tabular}

${ }^{\star}$ Pathovar reference strain.

$\dagger$ Repetition: $78 \cdot 3$.

cells. The cells were motile by means of one or two polar flagella. Colonies were colourless, translucent and formed a green fluorescent pigment on media B and A of King et al. (1954).

Each strain gave positive results for catalase, aesculin hydrolysis and aerobic acid formation from glucose (Hugh \& Leifson, 1953). The following characteristics were negative for all strains: hydrolysis of starch, formation of levan from sucrose, reduction of nitrate to nitrite, denitrification, arginine dihydrolase, DNase, indole production, formation of $\mathrm{H}_{2} \mathrm{~S}$ from sodium thiosulphate, utilization of D-tartrate on Dye's medium (Sands, 1990) and $\beta$-haemolysis of sheep blood. Production of oxidase was assayed on an early growth-phase culture with the aid of Bactident Oxidase test strips (Merck). Strains that developed a purple colour after 20-60 s, the time-span given by the manufacturers for a positive reaction, were considered oxidase-weak. Results of oxidase tests are shown in Table 2.

Assimilation of carbon substrates was determined by using Biolog GN MicroPlates as recommended by the manufacturers (MicroLog System, release 4.0). Results were read visually after $48 \mathrm{~h}$ incubation at $30^{\circ} \mathrm{C}$. A survey of the assimilation of substances is given in the species descriptions. Physiological tests that were different among the genotypes determined by ribotyping are shown in Table 2.

\section{Taxonomic conclusions}

The fluorescent pseudomonads studied, isolated from the phyllosphere of grasses, are composed of six genotypes as determined by ribotyping. The four that showed highest dissimilarity in ribopatterns and physiological features were chosen for further phylogenetic studies. Comparison of $16 \mathrm{~S}$ rDNA sequences between representative strains and almost all authentic Pseudomonas species revealed a clear affiliation to the genus Pseudomonas sensu stricto. DNADNA hybridization studies of these strains and their nearest phylogenetic neighbours (as determined by $16 \mathrm{~S}$ rDNA sequence comparisons) indicated separate species status for three of the genotypes studied.

This result is supported by phenotypic features. The yellow-pigmented, halophilic, marine bacterium $P$. gelidicola, which was not used in 16S rDNA analysis, differed clearly from the grass isolates in its ability to hydrolyse agar and requirement of $\mathrm{NaCl}$ for growth (Holt et al., 1994). By 16S rDNA analysis, strains of genotypes A and B (Pseudomonas trivialis sp. nov. and Pseudomonas poae sp. nov., respectively) were grouped with species characterized by a positive arginine dihydrolase reaction (Rudolph et al., 1990; Coroler et al., 1996; Elomari et al., 1996; Dabboussi et al., 1999; Baïda et al., 2002; Gardan et al., 2002; Ivanova et al., 2002; Munsch et al., 2002). They can thus be easily distinguished from their nearest phylogenetic neighbours. Phenotypic features that are effective for differentiation from physiologically similar species, characterized in particular by a negative arginine dihydrolase reaction, are shown in Table 4.

In contrast to the other genotypes, the representative strain of genotype D (Pseudomonas congelans sp. nov.) was a close neighbour to mostly oxidase- and arginine dihydrolase-negative species of Pseudomonas, which are potentially plant-pathogenic. Phenotypic features that are effective for differentiation from phylogenetically related species are shown in Table 4. Pseudomonas savastanoi, Pseudomonas ficuserectae, Pseudomonas meliae and Pseudomonas amygdali were included as separate species, although extensive DNA-DNA hybridization studies by Gardan et al. (1999) revealed that, together with certain pathovars of P. syringae, they formed a single genomospecies and should therefore be considered as synonymous. Unfortunately, the authors did not formally propose an emended species description, as no phenotypic features were found to distinguish them from six other genomospecies delineated 
Table 4. Differentiating characteristics of arginine dihydrolase-negative Pseudomonas species that are physiologically similar to the proposed novel Pseudomonas species

Taxa: 1, genotype A (P. trivialis); 2, genotype B (P. poae); 3, genotype D (P. congelans); 4, P. agarici [data from Young (1970), Hildebrand et al. (1994) and Delorme et al. (2002) (Biotype 100)]; 5, P. amygdali [Psallidas \& Panagopoulos (1975)]; 6, P. avellanae [Janse et al. (1996)]; 7, P. cannabina [Gardan et al. (1999) (Biotype 100)]; 8, P. cichorii [Billing (1970), Delorme et al. (2002) (Biotype 100) and Biolog database (release 4.0)]; 9, P. ficuserectae [Hu et al. (1991)]; 10, P. meliae [Hu et al. (1991)]; 11, P. kilonensis [Sikorski et al. (2001) (Biolog GN, API 20NE and 50CH)]; 12, P. savastanoi pv. savastanoi [Psallidas \& Panagopoulos (1975) and Gardan et al. (1992) (API 50AA, AO and CH)]; 13, P. savastanoi pv. glycinae [Billing (1970), Gardan et al. (1992) (API 50AA, AO and CH), Hildebrand et al. (1994) and Biolog database (release 4.0)]; 14, P. tremae [Gardan et al. (1999)]; 15, P. viridiflava [Billing (1970), Hildebrand et al. (1994) and Biolog database (release 4.0)]. Abbreviations: +, positive reaction; -, negative reaction; D, reaction differs among strains; ND, not determined.

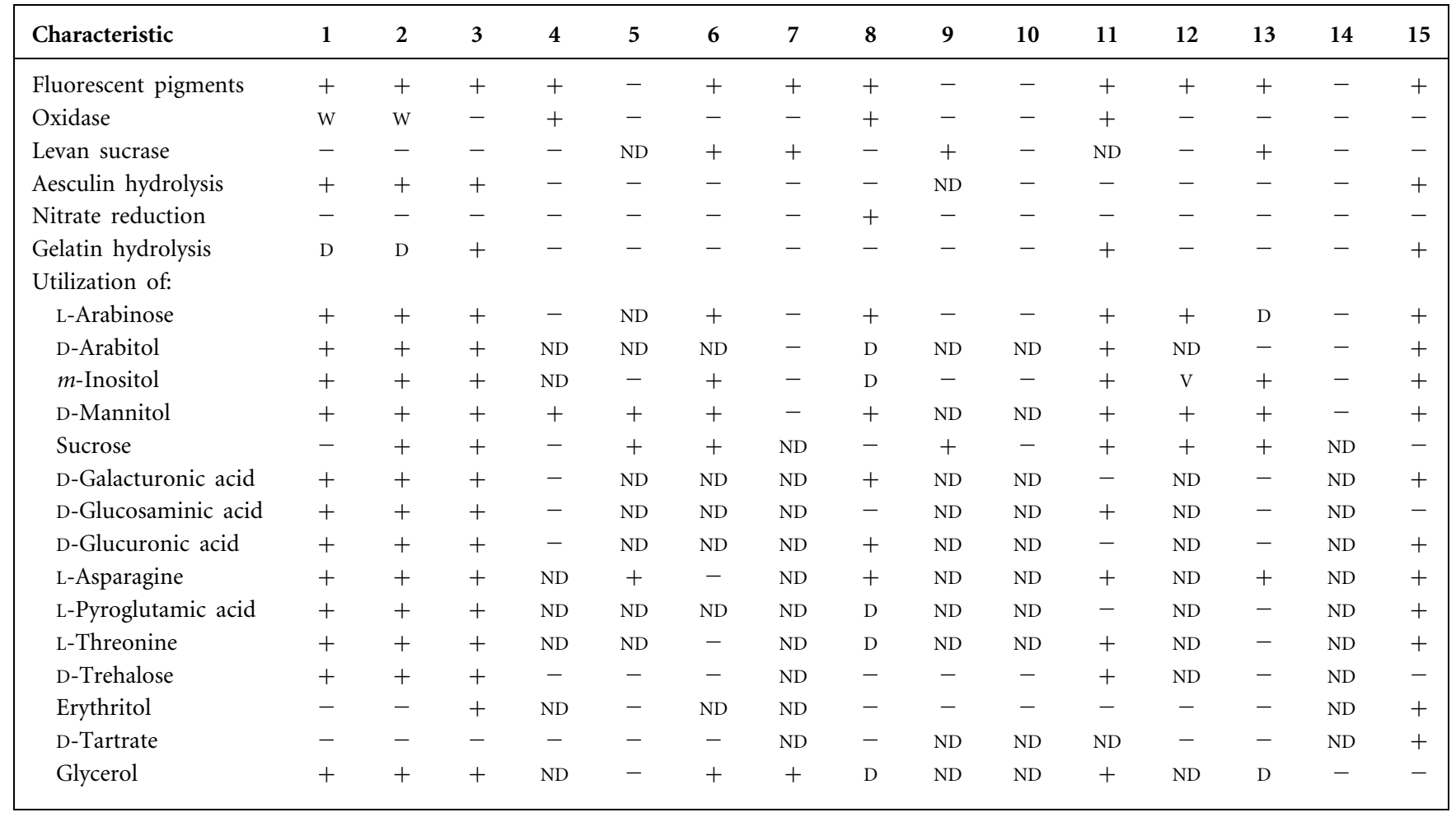

by DNA-DNA hybridization studies of 48 P. syringae pathovars.

Genomic heterogeneity of $P$. syringae pathovars, as revealed by DNA-DNA hybridization studies (Gardan et al., 1999), is linked with phenotypic differences as shown by Gardan et al. (1991) and makes species demarcation more difficult. Thus, several physiological features in Table 4 would be listed as variable, because of differences between pathovars. Therefore, P. syringae was not included in Table 4. However, phenotypic characterization of $48 P$. syringae pathovars and eight related species by Gardan et al. (1999) showed that $<10 \%$ of strains studied were able to utilize D-trehalose; they can thus be differentiated from the grass isolates of genotypes A, B and D (P. trivialis, P. poae and P. congelans, respectively), which are positive for this feature. Furthermore, characterization of phenotypic relationships by Billing (1970), Gardan et al. (1991), Hildebrand et al. (1994) and Young \& Triggs (1994) showed that pathovars of $P$. syringae can be differentiated from the grass isolates by a combination of the following features: levan sucrase, aesculin and gelatin hydrolysis, oxidase, ice nucleation activity and utilization of erythritol.

DNA-DNA hybridization studies of the representative strain of genotype E1 revealed an affiliation to the species $P$. cedrina. However, in contrast to the strains of P. cedrina that were isolated from Lebanese spring water (Dabboussi et al., 1999), grass-associated isolates were characterized by negative arginine dihydrolase and levan sucrase reactions. Furthermore, strains of genotype E1 were not able to assimilate D-trehalose, erythritol, D-sorbitol or adonitol. Thus, the grass isolates showed differences in physiological features that are normally used to distinguish species.

In summary, three of the four characterized grassassociated genotypes can be distinguished from all Pseudomonas species with validly published names on the basis of phenotypic and phylogenetic features. Consequently, the names Pseudomonas trivialis sp. nov., Pseudomonas poae sp. nov. and Pseudomonas congelans sp. nov. are proposed. 


\section{General description of novel Pseudomonas species and strains of genotype E1}

Cells are Gram-negative, non-spore-forming rods that occur as single cells. Colonies on King A and B media are white-yellowish, smooth with regular margins and produce a pigment with light yellow-green fluorescence on irradiation with UV light. Metabolism is respiratory. Optimal growth temperature is $21^{\circ} \mathrm{C}$. Growth can be observed at $4{ }^{\circ} \mathrm{C}$, but none of the isolates is able to grow at $41^{\circ} \mathrm{C}$.

Each species is positive for catalase, aesculin hydrolysis and aerobic acid formation from glucose. The following characteristics are negative: hydrolysis of starch, formation of levan from sucrose, reduction of nitrate to nitrite, denitrification, arginine dihydrolase, DNase, indole production, formation of $\mathrm{H}_{2} \mathrm{~S}$ from sodium thiosulphate, utilization of D-tartrate and $\beta$-haemolysis of sheep blood.

Results obtained with Biolog GN MicroPlates show that the species oxidize the following substrates: L-arabinose, D-arabitol, bromosuccinic acid, D-fructose, D-galactose, $m$-inositol, D-mannitol, D-mannose, methyl pyruvate, acetic acid, cis-aconitic acid, citric acid, D-galactonic acid lactone, D-galacturonic acid, D-gluconic acid, D-glucosaminic acid, D-glucuronic acid, $\alpha$-ketoglutaric acid, malonic acid, propionic acid, D-saccharic acid, succinic acid, glucuronamide, L-alaninamide, D-alanine, L-alanine, L-asparagine, L-aspartic acid, L-glutamic acid, itaconic acid, L-leucine, L-pyroglutamic acid, L-serine, L-threonine, Tween 80, $\gamma$-aminobutyric acid, urocanic acid, inosine, uridine and glycerol. None of the strains assimilated $N$-acetyl-D-galactosamine, adonitol, D-arabitol, $\alpha$-cyclodextrin, dextrin, L-fucose, gentiobiose, glucose 1 -phosphate, methyl $\beta$-D-glucoside, $\alpha$-D-lactose, lactulose, maltose, D-melibiose, D-raffinose, turanose, xylitol, sebacic acid, L-phenylalanine, thymidine, phenylethylamine or 2,3-butanediol.

\section{Description of Pseudomonas trivialis sp. nov.}

Pseudomonas trivialis (tri.vi.a'lis. L. fem. adj. trivialis trivial).

Cells are motile by one polar flagellum and are $1 \cdot 6-3 \cdot 3 \mu \mathrm{m}$ long and about $0 \cdot 8 \mu \mathrm{m}$ wide. Oxidase reaction is weak and ice nucleation activity is negative. In addition to the general description, the following substances are assimilated: formic acid, $\alpha$-D-glucose, $\alpha$-ketovaleric acid, glycyl L-glutamic acid, L-histidine, $\beta$-hydroxybutyric acid, $\alpha$-ketobutyric acid, D-alanine, L-proline, quinic acid, monomethyl succinate, succinamic acid, D-trehalose and Tween 40. None of the strains assimilates $i$-erythritol, glucose 6-phosphate, glycogen, glycolyl L-aspartic acid or D-psicose. Gelatinase, casein hydrolysis and utilization of $\mathrm{N}$-acetyl-D-glucosamine, D-cellobiose, L-rhamnose, $\alpha$-hydroxybutyric acid, $\gamma$-hydroxybutyric acid, DL-lactic acid, hydroxy-L-proline, L-ornithine, D-serine, DLcarnitine, putrescine, 2 -aminoethanol, DL- $\alpha$-glycerolphosphate, $p$-hydroxyphenylacetic acid and D-sorbitol are strain-dependent.
The type strain, $\mathrm{P} \quad 513 / 19^{\mathrm{T}} \quad\left(=\mathrm{DSM} \quad 14937^{\mathrm{T}}=\mathrm{LMG}\right.$ $\left.21464^{\mathrm{T}}\right)$, was isolated from the phyllosphere of grasses in Paulinenaue (Germany).

\section{Description of Pseudomonas poae sp. nov.}

Pseudomonas poae (po'ae. Gr. n. poa grass; N.L. gen. n. poae of/from grass).

Cells are motile by one polar flagellum and are $2 \cdot 5-3 \cdot 3 \mu \mathrm{m}$ long and about $0 \cdot 8 \mu \mathrm{m}$ wide. Strains show a weak oxidase reaction. Ice nucleation activity is negative. In addition to the general description, the following substances are assimilated: 2 -aminoethanol, $\beta$-hydroxybutyric acid, L-proline, L-histidine, DL-lactic acid, putrescine, quinic acid, succinaminic acid, sucrose, D-trehalose and Tween 40. None of the strains assimilates $\gamma$-hydroxybutyric acid, D-cellobiose, $i$-erythritol, glucose 6-phosphate, DL- $\alpha$-glycerol phosphate, glycyl L-aspartic acid, $p$-hydroxyphenylacetic acid, $\alpha$-ketovaleric acid, D-sorbitol or L-rhamnose. Gelatinase, casein hydrolysis and utilization of glycogen, $\quad N$-acetyl-D-glucosamine, $\alpha$-D-glucose, D-psicose, monomethyl succinate, formic acid, $\alpha$-hydroxybutyric acid, $\alpha$-ketobutyric acid, glycyl L-glutamic acid, hydroxy-L-proline, L-ornithine, D-serine and DL-carnitine are strain-dependent.

The type strain, $\mathrm{P} 527 / 13^{\mathrm{T}} \quad\left(=\mathrm{DSM} \quad 14936^{\mathrm{T}}=\mathrm{LMG}\right.$ $\left.21465^{\mathrm{T}}\right)$, was isolated from the phyllosphere of grasses in Paulinenaue (Germany).

\section{Description of Pseudomonas congelans sp. nov.}

Pseudomonas congelans (con.ge'lans. L. part. adj. congelans freezing/forming ice).

Cells are motile by one polar flagellum and are $2 \cdot 5-2 \cdot 9 \mu \mathrm{m}$ wide and about $0.8 \mu \mathrm{m}$ long. Strains are positive for gelatinase, casein hydrolysis and ice nucleation activity. Oxidase reaction is negative. In addition to the general description, the following substances are assimilated: DLlactic acid, 2-aminoethanol, $i$-erythritol, $\alpha$-D-glucose, glycyl L-glutamic acid, DL- $\alpha$-glycerol phosphate, $\alpha$-hydroxybutyric acid, $\beta$-hydroxybutyric acid, formic acid, L-histidine, monomethyl succinate, L-proline, D-psicose, quinic acid, D-sorbitol, D-serine, succinamic acid, sucrose, D-trehalose and Tween 40 . None of the strains assimilates $\mathrm{N}$-acetylD-glucosamine, DL-carnitine, D-cellobiose, glucose 6-phosphate, glycyl L-aspartic acid, $\gamma$-hydroxybutyric acid, hydroxy-L-proline, glycogen, $p$-hydroxyphenylacetic acid, $\alpha$-ketovaleric acid, L-ornithine, putrescine or L-rhamnose.

The type strain, P $538 / 23^{\mathrm{T}}\left(=\mathrm{DSM} 14939^{\mathrm{T}}=\mathrm{LMG} 21466^{\mathrm{T}}\right)$, was isolated from the phyllosphere of grasses in Paulinenaue (Germany).

\section{Acknowledgements}

We wish to thank Mrs A. Nandke and Mrs B. Selch (ZALF Paulinenaue), Mrs B. Sträubler (DSMZ - Braunschweig) and Mrs S. Weinert (ZALF - Müncheberg) for their excellent technical 
assistance. Furthermore, we would like to acknowledge Dr N. Weiss (DSMZ - Braunschweig) and Professor Dr H. G. Trüper (Rheinische Friedrich-Wilhelm-Universität, Bonn) for their help with the Latin construction of the species names. Furthermore, we are grateful to Dr L. Gardan for supplying strains for $16 \mathrm{~S}$ rDNA analysis.

\section{References}

Anzai, Y., Kim, H., Park, J.-Y., Wakabayashi, H. \& Oyaizu, H. (2000). Phylogenetic affiliation of the pseudomonads based on 16S rRNA sequence. Int J Syst Evol Microbiol 50, 1563-1589.

Baïda, N., Yazourh, A., Singer, E. \& Izard, D. (2002). Pseudomonas grimontii sp. nov. Int J Syst Evol Microbiol 52, 1497-1503.

Behrendt, U. (2001). Der Einfluß differenzierter Bewirtschaftungsintensität von Niedermoorgrünland auf die Entwicklung von Mikroorganismen-Gesellschaften in der Phyllosphäre von Gräsern. ZALF-Bericht no. 45. Müncheberg: Zentrum für Agrarlandschaftsund Landnutzungsforschung (ZALF) (in German).

Behrendt, U., Ulrich, A., Schumann, P., Erler, W., Burghardt, J. \& Seyfarth, W. (1999). A taxonomic study of bacteria isolated from grasses: a proposed new species Pseudomonas graminis sp. nov. Int J Syst Bacteriol 49, 297-308.

Billing, E. (1970). Pseudomonas viridiflava (Burkholder, 1930; Clara 1934). J Appl Bacteriol 33, 492-500.

Chun, J. \& Goodfellow, M. (1995). A phylogenetic analysis of the genus Nocardia with $16 \mathrm{~S}$ rRNA gene sequences. Int J Syst Bacteriol 45, 240-245.

Coroler, L., Elomari, M., Hoste, B., Gillis, M., Izard, D. \& Leclerc, H. (1996). Pseudomonas rhodesiae sp. nov., a new species isolated from natural mineral waters. Syst Appl Microbiol 19, 600-607.

Dabboussi, F., Hamze, M., Elomari, M., Verhille, S., Baida, N., Izard, D. \& Leclerc, H. (1999). Taxonomic study of bacteria isolated from Lebanese spring waters: proposal for Pseudomonas cedrella sp. nov. and P. orientalis sp. nov. Res Microbiol 150, 303-316.

Delorme, S., Lemanceau, P., Christen, R., Corberand, T., Meyer, J.-M. \& Gardan, L. (2002). Pseudomonas lini sp. nov., a novel species from bulk and rhizospheric soils. Int J Syst Evol Microbiol 52, 513-523.

Elomari, M., Coroler, L., Hoste, B., Gillis, M., Izard, D. \& Leclerc, H. (1996). DNA relatedness among Pseudomonas strains isolated from natural mineral waters and proposal of Pseudomonas veronii sp. nov. Int J Syst Bacteriol 46, 1138-1144.

Felsenstein, J. (1981). Evolutionary trees from DNA sequences: a maximum likelihood approach. J Mol Evol 17, 368-376.

Felsenstein, J. (1993). PHYLIP (phylogeny inference package), version 3.5c. Department of Genetics, University of Washington, Seattle, USA.

Gardan, L., Cottin, S., Bollet, C. \& Hunault, G. (1991). Phenotypic heterogeneity of Pseudomonas syringae van Hall. Res Microbiol 142, 995-1003.

Gardan, L., Bollet, C., Abu Ghorrah, M., Grimont, F. \& Grimont, P. A. D. (1992). DNA relatedness among the pathovar strains of Pseudomonas syringae subsp. savastanoi Janse (1982) and proposal of Pseudomonas savastanoi sp. nov. Int J Syst Bacteriol 42, 606-612.

Gardan, L., Shafik, H., Belouin, S., Broch, R., Grimont, F. \& Grimont, P. A. D. (1999). DNA relatedness among the pathovars of Pseudomonas syringae and description of Pseudomonas tremae sp. nov. and Pseudomonas cannabina sp. nov. (ex Sutic and Dowson 1959). Int J Syst Bacteriol 49, 469-478.

Gardan, L., Bella, P., Meyer, J.-M., Christen, R., Rott, P., Achouak, W. \& Samson, R. (2002). Pseudomonas salomonii sp. nov., pathogenic on garlic, and Pseudomonas palleroniana sp. nov., isolated from rice. Int J Syst Evol Microbiol 52, 2065-2074.
Hildebrand, D. C., Schroth, M. N. \& Sands, D. C. (1994). Pseudomonas. In Laboratory Guide for Identification of Plant Pathogenic Bacteria, pp. 60-80. Edited by N. W. Schaad. St Paul, MN: American Phytopathological Society.

Holt, J. G., Krieg, N. R., Sneath, P. H. A., Staley, J. T. \& Williams, S. T. (editors) (1994). Bergey's Manual of Determinative Bacteriology, 9th edn. Baltimore: Williams \& Wilkins.

Hu, F.-P., Young, J. M. \& Triggs, C. M. (1991). Numerical analysis and determinative tests for nonfluorescent plant-pathogenic Pseudomonas spp. and genomic analysis and reclassification of species related to Pseudomonas avenae Manns 1909. Int J Syst Bacteriol 41, 516-525.

Hugh, R. \& Leifson, E. (1953). The taxonomic significance of fermentative versus oxidative metabolism of carbohydrates by various gram-negative bacteria. $J$ Bacteriol 66, 24-26.

Ivanova, E. P., Gorshkova, N. M., Sawabe, T. \& 8 other authors (2002). Pseudomonas extremorientalis sp. nov., isolated from a drinking water reservoir. Int J Syst Evol Microbiol 52, 2113-2120.

Janse, J. D., Rossi, P., Angelucci, L., Scortichini, M., Derks, J. H. J., Akkermans, A. D. L., de Vrijer, R. \& Psallidas, P. G. (1996). Reclassification of Pseudomonas syringae pv. avellanae as Pseudomonas avellanae (spec. nov.), the bacterium causing canker of hazelnut (Corylus avellana L.). Syst Appl Microbiol 19, 589-595.

King, E. O., Ward, M. K. \& Raney, D. E. (1954). Two simple media for the demonstration of pyocyanin and fluorescein. J Lab Clin Med 44, 301-307.

Martin, K., Schumann, P., Rainey, F. A., Schuetze, B. \& Groth, I. (1997). Janibacter limosus gen. nov., sp. nov., a new actinomycete with meso-diaminopimelic acid in the cell wall. Int J Syst Bacteriol 47, 529-534.

Munsch, P., Alatossava, T., Marttinen, N., Meyer, J.-M., Christen, R. \& Gardan, L. (2002). Pseudomonas costantinii sp. nov., another causal agent of brown blotch disease, isolated from cultivated mushroom sporophores in Finland. Int J Syst Evol Microbiol 52, 1973-1983.

Psallidas, P. G. \& Panagopoulos, C. G. (1975). A new bacteriosis of almond caused by Pseudomonas amygdali sp. nov. Ann Inst Phytopathol Benaki 11, 94-108.

Rudolph, K., Roy, M. A., Sasser, M., Stead, D. E., Davis, D. E., Swings, M. \& Gosselé, F. (1990). Isolation of bacteria. In Methods in Phytobacteriology, pp. 43-86. Edited by Z. Klement, K. Rudolph \& D. C. Sands. Budapest: Akademiai Kiado.

Saitou, N. \& Nei, M. (1987). The neighbor-joining method: a new method for reconstructing phylogenetic trees. Mol Biol Evol 4, 406-425.

Sands, D. C. (1990). Physiological criteria - determinative tests. In Methods in Phytobacteriology, pp. 133-143. Edited by Z. Klement, K. Rudolph \& D. C. Sands. Budapest: Akademiai Kiado.

Schroth, M. N., Hildebrand, D. C. \& Panopoulos, N. (1992). Phytopathogenic pseudomonads and related plant-associated pseudomonads. In The Prokaryotes, pp. 3104-3131. Edited by A. Balows, H. G. Trüper, M. Dworkin, W. Harder \& K.-H. Schleifer. New York: Springer-Verlag.

Sikorski, J., Stackebrandt, E. \& Wackernagel, W. (2001). Pseudomonas kilonensis sp. nov., a bacterium isolated from agricultural soil. Int J Syst Evol Microbiol 51, 1549-1555.

Thompson, J. D., Gibson, T. J., Plewniak, F., Jeanmougin, F. \& Higgins, D. G. (1997). The CLUSTAL_X windows interface: flexible strategies for multiple sequence alignment aided by quality analysis tools. Nucleic Acids Res 25, 4876-4882.

Weisburg, W. G., Barns, S. M., Pelletier, D. A. \& Lane, D. J. (1991). $16 \mathrm{~S}$ ribosomal DNA amplification for phylogenetic study. J Bacteriol 173, 697-703. 
Young, J. M. (1970). Drippy gill: a bacterial disease of cultivated mushrooms caused by Pseudomonas agarici n. sp. N Z J Agric Res 13, 977-990.
Young, J. M. \& Triggs, C. M. (1994). Evaluation of determinative tests for pathovars of Pseudomonas syringae van Hall 1902. J Appl Bacteriol 77, 195-207. 